\title{
Public Administration and Ethics in Digital Era
}

\author{
Kemi Anthony Emina \\ Department of Religious Studies and Philosophy, Delta State University, Abraka, Delta \\ State, Nigera. \\ E-mail: eminakemi@yahoo.com
}

(Received: February-2020; Reviewed: February-2020; Accepted: March-2020;

Avalaibel Online: March-2020; Published: March-2020)

(7) (8) This is an open access article distributed under the Creative Commons Attribution License CC-BY-NC-4.0 @2020 by author (https://creativecommons.org/licenses/by-nc/4.0/)

\begin{abstract}
The ability to use and develop certain periods of societal skills of using and developing information and communication technologies greatly influences the fate and uses of these technologies in the economic, political, social and cultural spheres of society in the developmental and democratic indices of the world. Today, institutions need important information and data to maintain an efficient and productive life. Likewise, digitalization of information and data reveals new management understandings. Organizations are changing organizational structures and using hierarchical structures more flexibly and more efficiently. However, the benefits of progressively non-confidentiality of data and information are increasing in different fields, of which many social and cultural cataclysms can also follow. In particular, inequality in society is caused by the mutilation of privacy and trust In the Digital era, virtual action loses value and raises ethical issues. The inability to develop appropriate ethical principles for the virtual society deepens the effect of these problems on society. In this study, ethical perspectives of public administration in the Digital age are positively or negatively related to the situation.
\end{abstract}

Keywords: Digital Technology, Digital Era, Information Society, Ethics, Public Administration Ethic.

\section{INTRODUCTION}

With the transition to the information society in the globalization process, informationcommunication technologies have become life-determining. Today, individuals spend most of their time in computers, smartphones, tablets, virtual spaces, or other digital tools. The products of the digital age have made the individual do their work through the screen, communicate and circulate in virtual environments. Problems, relationships, and even family life in the workplace are carried out via email, Twitter, Facebook, Instagram, Youtube, or other social networks. Digital developments that have increased their impact in every field have also brought about radical changes in the functioning and understanding of public administration.

In the digital age, which is defined as a new phase in which the collected data and processed information can be stored in databases for years, institutions need a significant 
amount of data and information to maintain an efficient and productive life. The possibilities of communication technologies and innovations in internet technology affect the corporate structure in every aspect. By interacting with citizens and businesses, the activities in public administration are carried over the electronic environment, making it possible to use administrative services and practices directly and without intermediaries in the public domain. States are evolving towards a new management style based on efficient, efficient, and transparency based on the transfer of citizen-oriented services to the electronic environment (e).

Public administration mechanism; activities under its responsibility (security, justice, education, health, social security and local government services) are carried out through public officials, while the main purpose is public benefit. Those who benefit from public services expect public service officers to act within the framework of honesty, transparency and moral principles and to manage public resources fairly. Undoubtedly, ethical values play an important role in the efficient and efficient delivery of public services. Although ethics is defined as individual and social moral values, it is also referred to as acting according to professional principles and values. In this framework, ethical principles and codes ensure that public servants performing the service act impartially, objectively and honestly against citizens, and use their public powers correctly and in place.

The most important effect of the digital age in today's societies is that it can be controlled more than before is to enter into the way of life. States can learn more about people through information technologies having the opportunity to access information and concluding in a short time with the information collected from different information communication channels accessibility reveals the perception that the individual is under constant surveillance and corporate ethical values it eliminates over time. 'How much and how much' should you have the ethical issue attracted to the discussion area? In order to eliminate the negative perceptions about information, public accountability that their managers need to comply with in the decisions they make while conducting public services, integrity, social justice, impartiality, transparency, integrity of moral principles and values such as public interest they should be able to provide.

\section{A General Interest in Ethics Concept}

Ethics is a perspective that man produces for himself and responds to how he should behave. It is a system of values. Ethical and ethical values are not new concepts. As the origin of the word, the word 'Ethos' which means custom, or 'Ethikos', which means character, principle, human behavior, is shown in Greek. While the desired norms of behavior are expressed as morality, Ethical moral philosophy appears before us. He tries to understand the nature of the concept of morality (Kaypak, 2012: 17). Philosophers such as Socrates, Plato and Aristotle have put forward various views on ethics. Man regards the phenomenon of ethics as 'self-centered' in a way that emphasizes himself. Ethics is traditionally divided into three main areas in analytical philosophy: 'Meta-ethics, normative ethics and applied ethics'.

Many definitions are made on the concept of ethics. Literally, ethics examines the correct behavior in the light of ethical principles (Yüksel, 2011: 618). Immanuel Kant sees ethics as the philosophy of good mentality, not good actions. (Kant, 2003: 86) Zygmunt Bauman, on the other hand, defines ethics as the only moral rule, the only group of commands that consistently set up principles that each moral person must obey (Bauman, 2014: 33). In this way, ethics can be interpreted as a science about good and evil, or the general rules of action applicable to a 
particular group or every person (Özlem, 1997: 336). According to another definition, a philosophy that researches the values, norms and rules that form the basis of ethical, individual and social relations in terms of morality such as right-wrong or good-bad is the discipline (Gül \& Gökçe, 2008: 378).

The introduction of the concept of ethics into our literature dates back to the late 1980s (Gül \& Gökçe, 2008: 378). Traditional ethical understanding prevails over state apparatus, social conditions and value judgments since the 19th century. In the new period, which is described as the "modern" where the old was abandoned, ethical problems began to emerge with the introduction of technological and scientific innovations by moving out of ethical life (Y1lmaz, 2013: 15). The moral elements that emerge both in the individual and social dimensions of human life are also the problems of ethics. Therefore, although a discipline of philosophy, it emerges as a system of values in response to humanitarian weaknesses that have recently arisen in all areas of life (politics, medicine, environment, communication, sports, economics, etc.) (Kesgin, 2009: 146). Again, many professional groups are now working hard to reinforce their ethical codes and principles and to teach their members ethical values (Pieper, 2012: 30).

Annemarie Pieper likens ethics to a compass. Just as the compass does not describe where to go, it just indicates the direction, ethics does not show a specific action or behavior to the person, but the behavior that is considered true. It does not force the individual, the individual applies this behavior with his own free will (Pieper, 2012: 38). Ethics is a value that contains the ideal in a sense, what it should be. Society expects us to comply with ethical values, and it will be the social sanction that we will face when we do not.

When ethics is analyzed in terms of values, it emerges as either the values that arise in the relationship of the individual with other individuals or the values determined in the relationship of the individual with the state (Kuçuradi, 2011: 183-184). The concept of public ethics generally refers to the understanding of ethics and the system of ethical values in public service; It includes the principles and rules that public officials will comply within the framework of such an understanding and values in decision making and administrative processes while performing public service (Öktem and Ömürgönülşen, 2005: 232). Managerial ethics in general, integrity in management, trust, integrity, respect, etc. and its purpose is to apply these issues from manager to staff to everyone in the organization. Managerial ethics aims to be a balance factor by preventing the arbitrary use of public power, especially in public administration aiming at public service (Kaplan, 2009: 344-345).

While ethics in public administration is defined as a set of moral principles and values such as accountability, honesty, social name, objectivity, transparency, and public interest, which public administrators must comply with in their decisions while conducting public services; The management that adopts these principles and values and implements them in their decisions and transactions is called "ethical management" (Eryilmaz, 2010: 331). Managerial ethics or public service ethics consists of a series of principles and standards that include both unwanted forms of behavior that should be prevented and positive behaviors encouraged in all kinds of actions and transactions of administrative institutions and organizations (Uzun, 2011: 35).

The origin of the ethical debate in management also goes back to ancient times, it is evident that the modern sense of the ethical debate intensified since the 1970s. In the process of bringing public services to the public or in the internal functioning of government institutions, individual interests are taken into account rather than the public interest, public officials are involved in corruption, bribes, embezzlement, provide services to citizens where they serve, and 


\author{
246 Pinisi Discretion Review \\ Volume 3, Issue 2, March, 2020 Page. 242- 260
}

trust, and trust public administration. It has been observed that this situation has decreased gradually. This situation has forced many countries to issue new legal regulations to enforce and control their ethical values. Although the corruption in the political-bureaucratic system has been seen as a disease specific to underdeveloped countries for a long time, the large political and bureaucratic scandals that developed in the USA in the 1970s in the developed Western countries and which have passed into history as the "Watergate Scandal" have attracted the attention of the public to the phenomenon of corruption and ethics which as sparked debate. Since these years, the issue of public officials' ethical behavior has been on the agenda of many Western countries (Öktem and Ömürgönülşen, 2005: 231). The discussion of where to draw the boundaries came to the forefront in the distinction between individual benefit and public benefit for public officials.

\title{
Reasons that Enough Ethical Behavior in the Presentation of Public Services
}

Many reasons emphasize ethical behavior in public services. The most important of these are the 'Globalization' and the new management models emerging due to the understanding of public administration and the 'Digital Age', which is based on the development of information technology.

\section{Globalization}

Globalization, which is used to express the changes in almost every field from economy to politics, from politics to culture, from science to technology, is the fact that our world turns into a universal village as a result of the events occurring at one point affecting events at other points and the social relations that are affected by these events intensify worldwide (Y1lmaz and Horzum, 2005: 105). The change and transformation in the world with globalization results in public administrations being more sensitive to the demands of the societies and offering their services with a new understanding of public service. In addition to the structure and functioning of the state with the effect of globalization, significant changes have occurred in the state-citizen relationship (Biçer, 2009: 689). 
In a world where globalization is rapidly advancing and economic boundaries have disappeared, rapid developments in information and communication technologies have increased the economic gap between developed underdeveloped countries (Kaypak, 2009: 218). With the globalization, while the prosperity levels increased throughout the world, in parallel with this increase, the socio-economic structures of societies also collapsed. When the causes of the collapses in the political, social and economic structure that feed the global crises are questioned, it is seen that the resulting reason is corruption in the adoption and application of universal moral values (Uzun, 2011: 36). Both the companies and the governments of the economic crises that started in the USA with the globalization and affected the whole world have triggered them to renew themselves in terms of ethical codes and to be more transparent to the society. In parallel with the increasing technological developments, due to the increase in corruption day by day with the events causing social crises in societies such as income injustices and political corruption; In the national and international arena, it has come to the agenda to question the functioning of the institutions, and to put into practice the rules called "ethical code" when the laws are insufficient.

\section{Developments in Public Administration Approach}

The second important development that emphasizes ethical behavior in the world is the developments within the understanding of public administration. Especially with the new public administration (NPA), which started in the 1970s and became the priority of many countries in a short time, and 'good governance' based on participation since the 1990s, instead of the traditional public administration approach, it is far from transparent, strict bureaucratic procedures, able to compete and compete. A new management approach has come to the fore as a management style based on performance management. The groundbreaking by NPA has been a way of resurrection and a new paradigm for classical public administration, which has been weakened by current problems (Hughes, 2013: 143). In this regard, public administrations form policies in cooperation with different social actors, attach importance to local management, participate and be accountable, have a sensitive and flexible organizational structure, are sensitive about ethics and corruption issues, are transparent and open, and are not content with the sharing and processes which tend to shift towards the structures that take into account the performance, are sensitive to the demands and expectations of the client, and use the information and communication technologies to the maximum extent in service planning and delivery (Nohutçu \& Balc1, 2003: 18). Public administrations try to realize their way of communication - based on performance and participation through electronic or digital programs.

However, the expansion of the freedom of movement of the institutions with the business logic brings about the deterioration in the absence of a real inspection mechanism. All kinds of nepotism and corruption in institutions are possible and institutional reputation is damaged. Therefore, a demand has been brought to the fore to bring transparent understanding to the fore in order to protect corporate reputation in the state administration and to take a series of measures, especially the legislative infrastructure. For this, besides the need to increase the social responsibility by including the personnel firstly; The necessity of realizing abstract corporate social responsibility proactive and concrete corporate social responsibility messages within a reactive strategy has emerged (Dyck, 2014: 124). 


\section{Pinisi Discretion Review \\ Volume 3, Issue 2, March, 2020 Page. 242- 260}

The impact of the digital age on governance practices can be evaluated under three main themes: The first is reintegration. NPA has put public services into usable packages by bringing together many of the items devoted to discrete corporate hierarchies and transferring them to citizens and other civil actors. The reintegration approaches envisage a system far from the stereotyped centralist understanding of the old. Secondly, the need for unity based on principles fields, tight integration theme in public, unlike the unified holistic reform of the governance changes, agencies and all relations have changed between customers simplify and try to run. It also highlights the emergence of a more "agile" government that can respond quickly and flexibly to changes in the social environment. Third, changes made about digitization. It has made an important contribution especially in the sectors dealing with financial works (Dunleavy et al., 2006: 480).

Ethics is achieved through good governance in a sound and accountable public administration. It affects all decision-making processes related to the use of public resources and activities at all levels. When attention is paid to the principles of good governance, it is seen that the elements that a strong ethical infrastructure should have support these principles (TÜSİAD, 2005: 196).

\section{Digital Information}

The third important development that emphasizes ethical behavior in the world is digital developments that increase information technology and accordingly internet use. Information technology, which has emerged as a product of the use of electronic (microchip) single technologies as a result of the studies carried out in the space field in the USA since the 1960s, has started a new era (Koçak and Kavi, 2011: 2). In this period, which started the globalization process simultaneously, the rapid development of information and technology in the world, which is integrated with the developments in communication and transportation technologies, affects the management approaches of the countries, economic, social and cultural life. With this multifaceted change, the importance of information has increased within the framework of modern management approaches. As a system that will make the information available at any time, the realization of the electronic management approach, interpretation and systematization of the existing information has become a necessity (Kaypak, 2010: 257). Institutions, Youtube, Instagram, Facebook, Twitter, Blogs and other online platforms can increase the number of customers and their profit margins many times by organizing content based on customer satisfaction (Handley and Chapman, 2013: 17). The growth of the Internet, e-mail and the Web has enabled not only computer technology business systems to affect not only the back-office processes but also the development of relations between government agencies and civil society (Dunleavy et al., 2006: 478).

It is stated that when the free-market revolution in the economy and the information technologies revolution are combined with the effect of globalization, states emerge as a great power. The performance of the United States economy from 1995 to 2005 depends on these two factors. On the other hand, the growth caused by information technologies in Scandinavian countries is also linked to this (Koçak and Kavi, 2011: 6). In addition to this, it is seen that ethical values are ignored as one of the important causes of economic turmoil in public and private companies in the United States (USA) and other developed countries.

The change experienced through the digital age reveals the existence of a dynamic process (Yıldırım \& Öner, 2004: 49). Our country is affected by the Economic Cooperation and 
Development Organization (OECD) countries, although it is below the average in terms of the use of information technologies. As of 1999, about 8 thousand and 55 thousand computers web page using the Internet in Turkey, where between 300 and 400 thousand users, while it is estimated (Star, 1999: 149); According to the International Telecom Association (ITU) data, thanks to large investments in information and technology in recent years, it has reached 2 million after the 2000s, it has been revealed that 35 million of 78 million $\mathrm{n}$ blows are using digital technologies by increasing $1750 \%$ in the last decade (www.sgb.kulturturizm) .gov.tr, 2017).

The digital marketing agency has published the report "Digital in 2017 Global Overview" prepared in cooperation with 'We Are Social, Hootsuite'. In the 106 page report prepared with data collected from 238 countries; Up-to-date information and statistical data on the development of internet usage rates and digital areas were included. In the report, the data related to Turkey before striking the research should give place to the findings. According to the report ( www.dijitalajanslar.com, 2017):

More than half of the world now uses at least 1 smartphone.

$\checkmark$ Almost two-thirds of the world's population owns at least one mobile phone.

$\checkmark$ More than half of the web traffic worldwide now comes from mobile phones.

$\checkmark$ More than half of mobile connections around the world now use "broadband"

The growth in the report for Turkey; It is noteworthy that since January 2016, the number of internet users has increased by $4 \%$ to 2 million and the number of active social media users has increased by $14 \%$ to 6 million. The number of people using social media from mobile has increased by $17 \%$ in the last year. According to the same report, $95 \%$ of device users in Turkey is $75 \%$ of mobile phone owners and they use a smartphone. While the use of laptop and desktop computers is 51\%, it is seen that television still has an important place in our lives with $98 \%$ usage. During the day, users spend an average of 7 hours on the computer, 3 hours on the mobile phone, and 3 hours on social media platforms. The time spent on TV is an average of 2 hours. Finally, when we look at the most widely used social media channels in Turkey; open call 'Youtube', respectively. Facebook follows it with a little difference. Other prominent social media channels are among the highlights of the report, which is Instagram and Twitter (www.dijitalajanslar.com, 2017).

\section{Ethical Relations in the Digital Information Society}

Despite the brief history of the digital age that started with the communication of people with digital technologies, it has come to a position that surprisingly changes the lives of billions of people. It started with the use of the first electronic computers developed in the 1940s in 1946 for military purposes. Computers were originally used to decode Britons' encrypted messages. With the birth of the microprocessor after the 1960s, the new era was entering with the internet, which was used only in laboratory computers, in ordinary houses.

However, as these technologies said by Canadian Marshall Mc Luhan; In addition to the uncertainty about where an interaction such as

"We shape our tools, then our tools shape us" will lead us over time in terms of human values, we have also encountered problems with data collection, protection and use of the collected data set. It has become common and common to share our workplace problems, relationships and even family life through e-mail, messages, tweets, or blogs via the 
Internet, mobile phone or other digital tools. Therefore, it has begun to discuss where the digital world, which has become almost a way of life for millions of people, stands in terms of "privacy and publicity" (Chatfield, 2012: 20-21).

Ethics is seen as expressing the principles of right and wrong that individuals use as choices to guide their behavior as free moral units. However, what happened in the phase reached by digital information systems caused new ethical problems for individuals and societies. Digital information systems create opportunities for intense social change and thus affect the current distribution of power, money, rights and responsibility (Laudon \& Laudon, 2011: 124). While these technologies benefit the advancement of society and making life more accessible and easier to live in every respect; it can also facilitate crime and protection, and it brings with its social costs.

The emergence of the internet and electronic commerce has caused different importance to be attached to ethical issues in digital information. Thanks to digital technologies, the collection, processing, integration and distribution of information has become easier than ever and has raised new concerns about the protection of privacy and intellectual property rights. How to ensure accountability, obligation and control relations for society at every stage of digital life appears to be an important problem (Laudon \& Laudon, 2011: 124).

Science writer Steven Johnson at the TED Conference in California in 2003; It states that it resembles a city "built by a large number of people, not fully controlled by anyone, whose parts are intricately connected and still functioning as independent parts" (Chatfield, 2012: 104). Many questions await answers about how the changes in this complex city will change our minds positively and negatively, and how we can adapt to the digital age without losing our humanity. However, considering the difficulty of combating virtual terrorism and illegal broadcasts, credit card fraud, copyright and privacy violations, as well as future virtual terrorist wars, it becomes difficult to get a short distance in this regard. Because it is not possible to say that the electronic infrastructure and formations created by the states by using advanced technologies have been fully developed with rules and behavior models. Technology, which cannot be regulated and limited by law, causes physical and mental disruption in the life of the individual; It has been frequently emphasized recently that it can also disrupt social peace and integrity.

As the various forms of relationships between people and institutions are carried out through acts of art, new ethical issues arise in the context of human rights. Failure to develop appropriate ethical principles for virtual society is an important problem. This has the potential to severely disrupt the process of democratic dialogues and erode trust in relationships. Public view and control of the public, especially in the human rights dimension, can often go beyond the violation of moral dimensions. Beyond the short benefits provided by the realization of the security problems experienced after the war and migration phenomena, the traumas caused by the society keep the ethical and social dimension of digital life on the agenda.

In general, we can divide the technological trends that raise ethical problems into four groups. These (Laudon \& Laudon, 2011: 126);

- Doubling of computer power every 18 months

- Rapid reduction of data collection costs

- Developments related to data analysis

- Networking developments

Ethical and social and political issues are closely linked. We can compare this commitment to a stagnant lake on a summer day in a sensitive ecosystem. The stagnation shows that the 
relationship of individuals with social and political institutions runs smoothly within the framework of laws without any difficulties under certain rules. However, it is not difficult to estimate how suddenly emerging and rapidly developing digital information waves can destroy the social institutions in the pond in question overnight. In this process, it will take years for the development of etiquette and moral rules, expectations, social responsibility, politically correct attitudes or approved rules. At the same time, the new legal arrangements of political institutions and governments will take time and will often face various destructions. In this process, social dynamics may have to act within a legal gray area. Within this gray area, new ethical, social and political issues may emerge that should be dealt with on an individual, social and political level over time. These; include five dimensions: information rights and obligations, property rights and obligations, system quality, quality of life, accountability and control (Laudon \& Laudon, 2011: 126-146).

\section{Information rights and obligations}

The state is the visible concrete form of public space. It must be the ultimate intermediary of our popular will. However, it was revealed that the governments, which the public believed to be, were not in their relations with their own people in the Middle East, Far East Asia, Africa, and the state apparatus also needed control. 'Wikileaks' is designed to decipher the secret and confidential works of the countries by revealing the information that states have; Twitter, Facebook and Youtube channels such as to protect people in a merge and the name has contributed (Jarvis, 2012: 15).

The responsibility of being open to the public in our social structure can be seen differently between regions and even countries. In some countries, ethical or unethical behavior can be seen as ordinary behavior in another country. The recognition and disclosure of the digital era in a short time can provide personal and social benefits, as well as risk: The first is that quick and effective relationships can be established. We see that every information we want is just a research item and the people we want to meet are just a link. In addition, it can provide many benefits such as collecting blood for a patient with severe blood loss, gathering aid for a patient with cancer, and meeting for family and corporate meetings in a short time.

Second, thanks to fast and widespread communication, foreigners can become harmless and collaborate. Although some societies and even some countries are seen as potential enemies due to some superficial ironies, these prejudices can disappear in a short time thanks to digital communication. The third is the collaboration of being public. There are many advantages to being open to the public, whether governments are making policies or that a private company recognizes the product. In particular, we can see that the policies made based on the responses to the comments and surveys made by politicians on social media are more responsive. Or, a chocolate company has a better chance of getting an idea of whether the product is liked or not. On the other hand, the wisdom of the crowd floats freely leave. The more public, the information collected, analyzed and shared, the more information can be obtained. This is exactly what 'Google' company does. Larry Page, a co-founder of the company, states that although privacy concerns about shared information have been raised, more problems can be treated in general. The free float can also neutralize the tale of excellence. Since it discourages perfection, risk-taking and innovation, openness, and invention, it shows that nothing can happen without alternative, thanks to the wide supply of people. Publicity also immortalizes, adds fame, organizes and protects us (Jarvis, 2012: 61-85). 
However, there are also disadvantages to being public. The most important of these is the disclosure of privacy. As is known, in almost all societies on earth, there are taboos of the kind based on value judgments. It is natural to have these taboos in societies. However, some of these taboos are of the kind that can be misleading in almost every society in terms of moral values. There are also damages to the society of this kind of going public to the point of disclosing the private areas of individuals. To prevent disclosure of privacy on behalf of, the states and organizations "personal privacy" made under the name of various di There Regulative. Millions of employees are subject to surveillance with other forms of electronics and high technology. Information technology and systems threaten individual requests for personal privacy by making an attack on personal privacy cheap, profitable and effective.

Privacy is considered an important right to be protected by law in many developed countries including our country. However, the protection remains limited, as the private sector is comfortable in this regard and the deterrent measures are not sufficient. Because the information sent over the wide network on the internet passes through many different computer systems and different links before reaching the final destination. All online content related to which searches occurred in these systems, which sites were visited, what was viewed through these sites are recorded. Since each of these systems can control, seize, sort, and store communication through them, efforts to protect personal privacy may be inadequate ( Laudon \& Laudon, 2011: 134).

Maintaining privacy is very difficult today in environments with social channels such as Twitter and Facebook. However, it is not impossible. Because more people than ever are discussing and looking for their privacy. The main point here is the need to regulate the use of information rather than its collection. Otherwise, trying to prevent the disclosure and collection of information reveals the possibility of carrying a society back centuries.

So what should be the limits of the privacy area? Or what will be the limit in sharing information? Too many questions, such as Jarvis, states that the real problem is the decision of people to do with the information they get from social media. According to him, when publicizing information, it is necessary to predict how much that information will benefit the individual and society. Because privacy is ethics that govern the choices made by someone who receives someone else's knowledge. In other words, privacy is the ethic of knowing. Publicity is the ethics of sharing (Jarvis, 2012: 139). Information belonging to someone else is opened to the public.

I wonder what should be the public ethics? Jarvis responds to the question that one should definitely share valuable information and be generous in this regard. Stating that the information should be shared only for a reason, Jarvis should develop common standards and platforms in order to benefit from the information more, and public information should be benefited by considering the public interest. Here one should get information without people's knowledge or lie to obtain that information. It should be transparent about what to do with the information received and should not use it against people. In short, individuals will be able to maintain social ethics if they are transparent, open, respectful, valued and cooperative. Governments should also define privacy in order to protect social ethics and regulate the rules and laws accordingly (Jarvis, 2012: 142-143).

States, governments and companies must make the digital public available to the public within certain limits. However, an exaggeration should not be prevented enough to restrict access to information like in countries such as China, Tunisia, Uzbekistan, Egypt. Since 
companies like Google will consider the dissemination of this information for profit, it is possible to say that everyone agrees that governments and international organizations should impose certain restrictions. However, individuals should have various principles in many subjects that connect themselves and the society they live in. Because, in a Rand Corporation publication in 1998, James Dewar stated that "changes in the information age will be as striking as those in the Middle Ages", and that more striking effects will occur than expected. It predicts that the impact of Wikileaks-like publications will increase especially in terms of deciphering intelligence exchanges between countries (Jarvis, 2012: 251-256).

\section{Property rights and obligations}

Advances in information technologies weaken current practices and controls to protect intellectual property (trade secrets, copyright and patents) and make it difficult to protect property rights. Because the information in the internet environment can be easily copied and distributed over the network. There are no serious precautions to be taken for storing and distributing this distributed information and even putting it back on the market. One person can write a post written by someone else and write it under his own name and distribute it. The idea that ideas and knowledge become property objects and that this is a legitimate right has not been an accepted phenomenon.

\section{Accountability and control}

Accountability can be explained as the need to take responsibility against the relevant people regarding the use of their powers and responsibilities in an institution, to act in this direction, taking into account criticism and demands, and to take responsibility upon failure (Arcagök and Erüz). , 2006: 39). Accountability also includes establishing trust and directing in the state-citizen relationship (Gül, 2008: 73). Accountability is also accountability, openness, transparency, participation and compliance (Jones, 2006: 605). When the operation of the system is considered from an ethical perspective, it is also considered as measures regarding who will be responsible for the envisaged or faced threats regarding the provision of personal privacy and protection of property rights.

\section{System quality}

To ensure the safety of individuals, there is no steady-state regarding the quality and control standards of the data and system. Because the firm of software or programs used by almost every internet user, because the country is different, different standards emerge and it becomes difficult to control. However, some software minimizes system errors at very high costs. Otherwise, software errors, hardware plant failures and cost problems of low input data quality will be inevitable in a low system.

\section{Life quality}

In addition to important contributions to information life, information technologies also have negative effects on individual and social ethics. Quality emerges depending on the balance to be established between these two. If this balance cannot be maintained, we will come across 
as completely unknown, who will hold us responsible for bad results. Unless we can maintain the balance between center-environment, family, work, addiction, and vulnerability, negative social consequences will be inevitable.

With the developing technology, surveillance methods, and areas of the modern world have also been expanding. Over the past years, terms such as "virtual reality", "cyberspace", "online" have started to represent a type of communication outside the world, which is determined by the geographical and institutional boundaries we live in. As a result of our joint use of network-based technologies, we have created a connection experience that includes many things that are real, simulated and expanded in various ways. AAs an avatar in our lives, it enables a program like "second life" to enter into our lives, with which we can perform all kinds of activities by representing different online simulations (Coleman, 2012: 33-37). In this secondary life, where the shelf life of the visible face is reduced, in the shopping, which David Lyon describes as "fluid modernity", we can see that the once-rigid and constant surveillance has become much more flexible and dynamic in the workplace, at home and therefore in every place of life (Şahin, 2015: 41). People use street media, hackers, Fawkes masked people on the common platform using social media tools; "Digital activism" is carried out for public benefits, such as raising money for cancer patients and earthquake victims (Turhan, 2017: 41). Contemporary network-based media use, identity s between foresees determine the identity and to reinforce rather than a continuous change (Coleman, 2012: 108).

On the other hand, some researches have revealed that in digital life, people can discover their self by changing many selves, and they can appear on the network as "more like themselves" or "as they want to be". Accordingly, the use of the internet in the digital age has become a social laboratory for the reconstruction of the self. In the virtual reality of the internet, we can become the fashion and creation of our self (Coleman, 2012: 107).

\section{Public Ethics in the Digital Age}

Two factors govern and influence the behavior of public officials externally and internally in the execution of public services: One is the law and the other is the ethical values. While the law externally determines and controls the behavior of public officials; ethical values manage and control behavior internally (Özdemir, 2008: 182).

Laws and rules that play a role in determining behavior from outside force public officials to act in the public interest. From this point of view, public administration ethics means that public employees conduct all kinds of behaviors according to laws, ethical codes and various rules. When considered as the internal determinant of the behavior of public officials, public administration ethics means that public officials perform their actions based on individual moral values (Koçak and Kavi 2011: 19). In this context, 'ethical committees' were established by law in our country in 2004. Public officials are signed with a 'public officials ethics agreement' that they will act ethically. Public officials will work on behalf of the public, for the public benefit and in the company of public authorities. Nevertheless, these developments do not eliminate the problem of the applicability of ethical and ethical values in institutions. Unethical behavior continues and is put to logic.

Since public services are accepted as activities that meet the public interest, they are in parallel with the transformation, the quality and effectiveness principle, citizenship principle, participation, and transparency (openness) principles should be taken into consideration (Avc1, 2014: 109). Because ethics plays an important role in creating trust in governments and its 
institutions as an important balance factor against arbitrary uses in public power (Uzun, 2004: 155).

The main problems of public administration in many countries around the world are bad governance, unqualified workforce, inefficient use of resources, misconduct, corruption, corruption, etc. negativities are included. These problems not only disrupt the public financial system in a country but also cause many problems in individual, household, society and government relations. As the unethical behaviors such as corruption and favoritism in the field of management begin to emerge in the public and pose serious problems, the concepts of public ethics or administrative ethics are among the topics that are emphasized. Public ethics concerns not only the undeveloped or developing country administrations, but also the developed countries, and with the new management approaches, ethical comprehensive, reorganization efforts are undertaken. Today, ethical principles are written in legislation and ethical codes and systematized by binding to sanctions (TUSİAD, 2005: 19).

Digital or technological transformation in public administration has continued its pace by realizing significant transformations at the level of paradigm that I call the information age or network society after the 1980s and paved the way for groundbreaking theoretical developments in the discipline. In this framework, new public administration, postmodern public management, governance, e-government, total quality management and many similar understandings have emerged. A new phase has been initiated within the framework of the "governance" approach of the information age society that has principles such as participation, transparency, citizen orientation and accountability. Especially in the Scandinavian countries, after the 1990s, they appear to be more intensely involved in the effort to establish and develop ethical rules and standards and regulatory supervisory institutions in the face of increasing pressure from the public to establish a "good" and "ethical" administration.

The state's customer orientation and increasing demands of citizens, delegation of authority and accountability, increased autonomy of local governments (TUSIAD, 2003: 27-36), international organizations such as the UN, World Bank, EU and OECD, put the fight against corruption on the agenda of public administration reforms and it was effective in restructuring ethical behaviors (Demirci \& Genç, 2008: 47).

With the transfer of all kinds of activities on the electronic environment in the public administration, the management services and applications in the public field have started to be used without tools. As internet services have become an important element of social life, digitalization of the state and the use of information and communication technologies in the provision of public services have enabled the implementation of concepts such as e-government, e-democracy, and e-governance. Information society culture based on flexibility, downsizing, rapid decision making, accountability, transparency, right to information, political participation and democracy. On the one hand, the state has presented the meat meats offered to the public for online information; On the other hand, citizens and other segments became followers of the services provided. Government services have become transparent and accountability has increased due to the understanding of transparency (Doğan \& Ustakara, 2013: 8). This has emerged with the attempt to ensure citizen participation in line with the New Public Management (YKY) approach within the framework of the failure of the holistic social development and urbanization programs that came to the agenda after the Second World War in the 1960s (Karkin, 2012: 44 ).

Today, the stage where democratic values have come has brought ethical debates to the agenda in public administration. Public administration is not only a technical and political 
phenomenon but is also considered an ethical phenomenon. In addition to the principle of public interest in public administration, the problem of trust of the citizen, which has recently gained importance, is an important part of public administration ethics (Koçerber, 2008: 67). The speed of communication and the strengthening of civil society have increased the sensitivity to ethical behaviors more (Biçer, 2009: 689). Ethics has been stripped of the bureaucratic structure and assumed the image of 'democratic ethics'. Through the Internet, there was the opportunity to reach management and managers from anywhere, 24 hours a day (7/24). The internet has opened all its doors to the 'm-democracy' application with smartphones. Increased use of social media, the limits beyond 'global e tiger' has led to the concept.

Digital technologies are not only communication, but also tools with cultural, social and economic dimensions that connect individuals and organizations around the world today. Although information technologies spread rapidly to the social and economic lives of societies, academics and professionals working in the field of industrial relations also examine the effects of this process on working life. All kinds of promotional activities are carried out on the Internet. In addition, information technology and communication technologies ensure that governments are more transparent and more democratic and help both state and private sector decision making. While ensuring the public's participation in both management and decision making, it leads to less corruption, more transparency, trust, increased income and reduced costs. Information technologies play a role in the infrastructure of many cities developed around the world (Koçak and Kavi, 2011: 13):

- Advanced electronic public services,

- Modernization and continuous change of governments,

- Strong local democracy,

- It increases participation in decision-making processes and thus makes decisions fast and powerful.

However, the change with digital technologies has increased the opportunities for monitoring and supervision, as it would hopefully increase democracy and enable the public to participate more in management. Programs are developed to show what the employees at the workplace do during their working hours. Life has lost its naturalness to the cities. Everything is recorded. Although this is beneficial in terms of catching criminals and seeing the moment of the incident, it is one of the most discussed issues. How much should the state observe and record, how much should it read and listen, is there a limit to this? They are still the issues under discussion.

Technologies that have become an inseparable part of human life and the body and continue to develop at a great speed keep the society and institutions under surveillance and make them dependent on themselves. In democratic societies, while the state should manage its institutions through non-governmental organizations, security, etc. at the point reached. With arguments, the state monitors and supervises individuals in almost all countries, including developed democratic countries. This situation leads to the elimination of the non-governmental organizations that sustain democratic countries and the complete or partial destruction of individual freedom.

\section{CONCLUSION}

In the last century, advances in globalization and information and communication technologies and developments in the public administration approaches of the states have been 
interconnected, which have significantly affected our globe. With the transition from the industrial society to the information society, technological developments have started to determine the world agenda. Innovations that were not possible in the past years come after each other at a dizzying speed. Technology has accelerated life. Accelerated life increases expectations in services. The new public management approach is the reflection of these expectations to the public with the business management logic. In order to meet the expectations in service requests, the state turned towards electronic services. Many services that can be done in public institutions are tried to be provided in a faster, quality and up-to-date fashion.

In the digital period, which has increased its speed since the 1960s, the provision of public services with information and communication technologies has found application in local administrations after the central administration. All service and business processes have been redefined in accordance with e-transformation. Internet services have become an important element of social life and the world has become smaller. It is a fact that the information technologies used make our lives easier and have important contributions to human life. Publicprivate borders have disappeared with the intensive use of internet. Spatial and timeless connections can be made. This provides great convenience in terms of the interaction of technology-sensitive public institutions and the formation of state-citizen communication.

On the other hand, the business also has an individual and social ethical dimension. Digital networks can be used by the government for surveillance purposes. The public bureaucracy, which is morally responsible for society, needs to be more sensitive and careful when using information technologies. Individuals and institutions should also have this sensitivity. the internet is not an open space where everyone can do anything. Since there are no serious precautions against crime incentives and crimes created in the internet environment, it becomes difficult to take a short distance in terms of acting ethically. Besides the states, terrorist elements can collapse the entire social and bureaucratic network of a state thanks to computer hackers in virtual environments. Ethical terrorist elements are not expected to be practiced. Immoral images and publications can also push the conscience and limits of society.

The ethical problem takes place on the basis of correct action and is also an expression of a collective consciousness. Information communication technologies are an achievement in terms of public participation in management and the realization of democratic management. However, in the present day, where the individual's freedom aspect comes to the fore, it is seen that private life violations caused by information technologies constitute the ground for backward progress in the context of democratization and human rights. It is a positive step for public administrations to behave in compliance with the moral principles and values such as accountability, honesty, social justice, impartiality, transparency and public interest while conducting public services. But it is not enough. It is necessary to expand an e-culture based on moral basis and to establish a cyber-security ground.

\section{REFERENCES}

Al, H. (2005). "Combating Corruption in Turkish Public Administration: Traditional Bureaucratic Structure and New Ethical Values", Ethics Symposium Proceedings Book in Politics and Administration, 18-19 November 2005, Sakarya University Faculty of Economics and Administrative Sciences, 239-249.

Arcagök, M. Sait \& Erüz, E. (2006). Public Financial Management and Control System, Publications of Finance Account Experts Publications, Ankara. 
Avc1, M. (2014). "Contraction in the Administration's Public Service Activities and Transformation: Privatization and Regulation n" TAAD (Journal of the Justice Academy of Turkey), 5 (16): 105-139.

Bauman, Z. (2014). Postmodern Ethics, (Translated: Alev Türker), Detay Publications, Istanbul.

Biçer, İ. (2009). "Implementation of the Ethics in Public and Private Sector Organizations, Public Ethics", Public Ethics Symposium Proceedings 2, 25 to 26 May, the Public Administration Institute for Turkey and the Middle East, Ankara, 689-698. Bruce, W. (Ed.) (2001). Classics of Administrative Ethics, Westview Press, Colorado.

Chatfield, T. (2012). How Do We Adapt To The Digital Age? (Translated: Levent Konca), Sel Publishing, Istanbul.

Coleman, B. (2012). Hello Avatar- Rise of the Digital Generation (Translated: Emrah Bilge), Mediacat Publishing, Istanbul.

Demirci, M \& Genç, Fatma N. (2008). "Restructuring the Public Ethics Reform Process in Turkey", Journal of Public Administration, 41 (2): 43-58.

Doğan, Kadir C. \& Ustakara, F. (2013). "On the Relationship between E-Government and EGovernance as a Transformation to the Public Sector", Global Journal of Economics and Business Studies, 2 (3): 1-12.

Dunleavy P .; Margetts H., Bastow, S. \& Tinkler, J. (2006). "New Public Management Is Dead: Long Live Digital-Era Governance", Journal of Public Administration Research and Theory (JPAR T), 16 (3): 467-494, http://www.jstor.org/stable/3840393, 06 -11-2017.

Dyck, Fons V. (2014). New Generation Advertising: New Rules for the Digital Age, (Translated: Volkan Eke), The Kitap Publications, Istanbul.

Eryilmaz, B. (2010). Public Administration, Instructor Publishing, Ankara.

Gül, H. and Gökçe, H. (2008). "Organizational Ethics and Components", Suleyman Demirel University Faculty of Economics and Administrative Sciences , 13 (1): 377-389.

Gül, Serdar K. (2008). "Accountability in Public Administration and Security Services", Journal of Police Sciences, 10 (4): 71-94.

Handley, A. \& Chapman, CC (2013). Rules of Content Management in the Digital Age (Çe v: Zeynep Kökkaya), Mediacat Publishing, Istanbul.

http: $\quad$ / / www.dijitalajanslar.com/internet - and - social - media - user - statistics - 2017 / 08.10.2017. http: //www.wikipedi to. organ. What is an avatar? 10/10/2017.

Hughes, Owen E. (2013). Public Business and Management. (Translated: Buğra Kalkan; Bahadır Akın \& Şeyma Akın), Bigbang Publications, Ankara.

In http://sgb.kulturturizm.gov.tr/tr,15252/turkiye - the internet - usage - in the face - 1750 artti.html, 10/08/2017.

Jarvis, J. (2012). E-Social Society: The Effect of Social Media on Business and Daily Life in the Digital Age . (Translated: Çağlar Kök), Mediacat Publishing, Istanbul.

Jones, T. (2006), "The Governance and Accountability of Policing", Handbook of Policing (Ed. Tim Newburn), Willan Publishing.

Kant, İ. (2003). Lessons on Ethica Ethics (Translated: Oğuz Özügül,) Window Publications, Istanbul.

Kaplan, Ç. (2009). "Ethics in Public Administration and Public Employees' Perception of the Concept of Ethics", Süleyman Demirel University Journal of Faculty of Economics and Administrative Sciences, 14 (3): 343-355. 
Karkın, N. (2012). "The Concept and Process of E-Participation: The Possibility of Citizen Contribution to the Public Policy Formation Process", Socioeconomics / January-June 2012 (1): 42-62.

Kaypak, Ş. (2009). "E-Transformation in the Globalization Process and Its Reflection to Municipalities", 7th International Information, Economy and Management Congress Proceedings Book, 30 October 1 November 2009, (Ed: İ . Güran Soft), Yalova and Istanbul University, Yalova. 215-234. Kaypak, Ş. (2010). "E-Government Structuring in E-Transformation Process and Its Reflection to Antakya Municipality", 8th International Information, Economy and Management Congress 28-31 October 2010 Proceedings Book, (Ed: İ. Güran Soft), Istanbul University, Istanbul, 257-272.

Kaypak, Ş. (2012). "An Ethical Approach to Environmental Peace", Abant Izzet Baysal University Faculty of Economics and Administrative Sciences International Journal of Economics and Social Studies, 8 (1), Spring, 1-30.

Kesgin, A. (2009). "On Ethics", Religious Studies, XII (35): 143-160.

Koçak, O. \& Kavi, E. (2011). Ethics in Working Life, Ekin Kitabevi Yayınları, Bursa.

Koçerber, S. (2008). "Control Ethics in the World and in Turkey", TCA Journal, (68) JanuaryMarch, 65-90.

Kuçuradi, İ. (2011). Ethics, Turkey Philosophical Society Publications, Ankara.

Laudon, Kenneth C. \& Laudon, Jane P. (2011). Governance Information Systems- Managing Digital Business, (Translation Ed. Uğur Yozgat), Nobel Publishing, Ankara.

Leveraging Technology: E-Municipality Applications in Turkey ", The Turkish Online Journal of Educational Technology (TOJET), 3 (1): 49-60.

Mediterranean, Y . (2016) . Racism on the Internet (Translation: Özgür Bircan), Istanbul Bilgi University Publications, Istanbul .

Nohutçu A. \& Balcı A. (2003). "New Perspective and Dynamism of Public Administration: From Public Administration to Public Administration Approach", Contemporary Approaches in Public Administration (Der: Asım Balcı \& Ahmet Nohutçu), Seçk in Yayınc1lık, Ankara.

Öktem, K. \& Ömürgönülșen, U. (2005). "A General Framework for Ethics Studies in Public Administration”, II. Ethics Symposium 18-19 November 2005, Sakarya University Faculty of Economics and Administrative Sciences Publication, Sakarya, 231-237.

Özdemir, M. (2008). "Ethics in Public Administration", Zonguldak Karaelmas University Journal of Social Sciences, 4 (7): 179-195.

Özlem, D. (1997). Today Philosophy Disciplines, Revolution Bookstore, Istanbul.

Pieper, A. (2012). Introduction to Ethics (Translation: Veysel Atayman \& Gönül Sezer), Detay Publications, Istanbul.

Şahin, S. (2015). "Digital Age and Transformations in Art", Kocaeli University Faculty of Fine Arts Journal Appearance (1) December, 38-50.

Turhan, Dur muş G. (2017). "Digital Activism”, Suleyman Demirel University Journal of Social Sciences Institute, 1 (26): 26-44.

TÜSİAD (2005), "From Ethics to Ethics in the State: Ethics in Public Administration Conceptual Framework and International Practices", TÜSİAD Yayınları, İst anbul.

Uzun, T. (2004). "Ethical Issues in Public Administration, Administrative and Political Corruption" Turkey in the EU Process (Ed: Turgay \& Sarah Long Ozen), Outstanding Publications, Ankara.

Uzun, Y. (2011). "Ethical Management in Public Administrations", TCA Journal, (80), 33 -56. 
Volume 3, Issue 2, March, 2020 Page. 242- 260

Yıldırım, U. \& Öner, Ş. (2004). "Education-Informatics in Local Governments in the Information Society Process

Yildiz, M. (199 9). "Participation in Local Government New Channel Internet: the United States and Electronic Public Information Network in Turkey", Journal of Contemporary Local Governments, 8 (4): 144-156.

Y1lmaz K \& Horzum, B. (2005). "Globalization, Information Technologies and University", İnönü University Faculty of Education Journal 6 (10): 103- 121.

Y1lmaz, M. (2013). Moder to Postmoder Art, Utopya Publishing, Ankara.

Yuksel, C. (2011). "Ethical Values in Politics in Our Country and in the World", Istanbul University Faculty of Law Magazine, 69 (1-2): 617-634. 